\title{
ACETYLCHOLINE IN THE LARVAL FOOD, HONEY, AND STORED POLLEN OF A STINGLESS BEE, MELIPONA QUADRIFASCIATA *
}

\author{
JOHN H. WELSH 1, PAULO NOGUEIRA-NETO, CELSO P. JAEGER 2 \\ and ANA AMÉLIA ANCONA LOPEZ \\ University of São Paulo, Brazil \\ and
}

The Biological Laboratories, Harvard University

Cambridge, Massachusetts U. S. A.

Acetylcholine has been found in royal jelly of the honeybee, Apis mellifera $\mathrm{L}$. in amounts ranging from about 0.5 to $1.5 \mathrm{mg}$. per gram (Watanabe, 1955; Henschler, 1956; Jacoli, 1956; Colhoun and Smith, 1960) The food of worker and drone larvae also contains similar levels of acetylcholine (Henschler and von Rhein, 1960) It is present in honey of Apis, although in much smaller amounts (see Henschler, 1954, for early references; also Goldschmidt and Burkert, 1955; Watanabe, 1955) The source of the large amount of acetylcholine in royal jelly, and its biological role, are not yet clear (e. g. Colhoun and Smith, 1960)

During a visit of one of us (J. H. W.) to Brazil, there was an opportunity to look for acetylcholine in the larval food, honey, and stored pollen of one of the stingless bees, Melipona quadrifasciata Lep., popularly called MANDAÇAIA. In larval food it was found in an amount equivalent to that reported for $\boldsymbol{A p i s}$. It was also present in the honey and stored pollen.

It is of much interest that the food of a bee quite unrelated to Apis mellifera contains a rich supply of acetylcholine.

\footnotetext{
* Received for publication on may 5th, 1963.

1 Work done in Department of General and Animal Physiology, University of São Paulo while J. H. W. held a Fulbright Research Fellowship.

2 Present address: Instituto de Fisiologia Experimental, Faculdade de Medicina, Pôrto Alegre, Brasil.
} 
The present paper deals mainly with the identification and quantitative estimation of the acetylcholine but, in addition, it will report our preliminary efforts to determine the source of this substance.

\section{MATERIALS AND METHODS}

The larval food, honey, and stored pollen were obtained from colonies of Melipona quadrifasciata maintained by one of us according to methods already described (Nogueira Neto, 1957 a, b)

Larval food was pipetted or extracted by syringe from brood cells in which eggs or newly hatched larvae were found. Effort was made to use only the upper liquid portion of the larval food. It was used on the same day it was removed; refrigerated at $4^{\circ} \mathrm{C}$; or dried under reduced pressure and stored at $4^{\circ} \mathrm{C}$. Stored pollen was removed from the "pollen pots" and used fresh or dried as was the larval food. Honey, from the "honey pots" was removed and sent by air to Cambridge, Massachusetts, for study .

Bioassays: Fresh larval food, and honey, were diluted with appropriate perfusion fluids for identification and estimation of acetylcholine by biossay Dried larval food and pollen were extracted with water or ethanol. Ethanol extracts were evaporated under reduced pressure and the residue dissolved in an appropriate perfusion fluid before bioassay.

Acetylcholine was estimated in equivalents of acetylcholine chloride using the following test preparations: a) longitudinal muscle of the sea cucumber, Holothuria grisea, after the methods of Ambache and Sawaya (1953) and Sawaya and Ancona Lopez (1959); b) on the isolated median rectus abdominis muscle of a Brazilian toad, Bufo ictericus, after the method that generally employs the rectus abdominis of a frog (e. g. Chang and Gaddum, 1933); c) on the isolated ventricle of the clam, Venus mercenaria after the method of Welsh and Taub (1948) or Welsh and Twarog (1960) Certain acetylcholine potentiators and blockers, and destruction by $\mathrm{NaOH}$, were used to help confirm its identification .

Chromatography: Paper chromatography was employed mainly to confirm the identification of acetylcholine in larval food and stored pollen, although it also revealed the presence of choline, glycine 
betaine. and a substance with properties suggesting that it might be a choline ester other than acetylcholine.

Fresh larval food was spotted directly on paper or dried larval food was extracted with $70 \%$ or $95 \%$ ethanol before spotting. Differences in the results obtained with the two procedures will be discussed later. Pollen was extracted with ethanol in preparation for spotting. Acetylcholine and choline standards as well as a few other quaternary ammonium bases, were spotted for reference.

Most chromatograms were developed for a period of 12 hours in n-butanol-acetic acid-water $(60: 15: 25)$ The ascending method was generally used. Dragendorf's reagent was used for detecting quaternary ammonium compounds (Breghoff, Roberts and Delwiche, 1953)

In some instances, horizontal strips of chromatograms were eluted with distilled water and the eluates assayed for acetylcholine - like activity

Bioassay of extracts of parts of MELIPONA QUADRIFASCIATA:

In two experiments, the acetylcholine content of head, thorax and abdomen was estimated by bioassay In the first, 15 young adult bees were used; in the second, 20 older bees .

Further details concerning methods will be given under Results.

\section{RESULTS}

1 Larval Food:

a) Bioassays .

When appropriate dilutions of fresh or refrigerated larval food were applied to any one of the test preparations, the response was similar to that produced by acetylcholine. The action of the extract could be blocked by a suitable blocking agent, potentiated by an anticholinesterase, and destroyed by the addition of $\mathrm{NaOH}$ to $\mathrm{pH} 9.0$ followed by warming.

A typical series of tests done on the isolated rectus abdominis muscle of Bufo ictericus is shown in Fig. 1 Here it was found that a $10^{-3}$ dilution of fresh larval food produced a contracture intermediate to those produced by $10^{-5}$ and $10^{-6} \mathrm{gm}$. acetylcholine per 
milliliter of bathing fluid. After treating this muscle for $15 \mathrm{~min}$. with benzoquinonium (Mytolon), a synthetic neuromuscular blocking agent, the same amounts of acetylcholine and larval food were completely blocked.

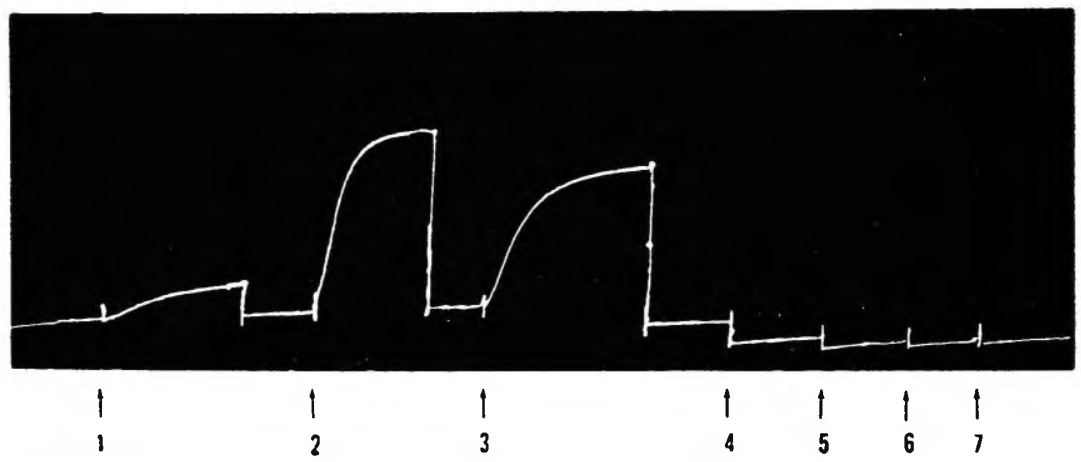

FIG. 1. Block by benzoquinonium of the excitor actions of acetylcholine and larval food on the rectus abdominis muscle of Bufo ictericus. Concentrations are expressed as weight per milliliter of bath fluid.

1) Acetylcholine chloride

2) " "

3) Fresh larval food

4) Benzoquinonium

5) Acetylcholine chloride

6)

7) Fresh Iarval food

$$
\begin{aligned}
& { }_{10-6} \mathrm{gm}^{-} / \mathrm{ml} \text {. } \\
& \text { 10-3" " } \\
& \text { 10-4" " } \\
& \text { 10-6" " } \\
& \text { 10-5 " " } \\
& 10^{-3} " \text { " }
\end{aligned}
$$

An example of the use of the toad rectus abdominis muscle in the quantitative estimation of acetylcholine activity in larval food is shown in Fig. 2. In this experiment a sample of dried larval food was reconstituted with distilled water and a series of dilutions made with amphibian Ringer's solution. A concentration of $10^{-6} \mathrm{gm}$ larval food $/ \mathrm{ml}$. of bathing fluid gave a just perceptible response. After three higher concentrations of larval food extract and two of acetylcholine chloride had been applied to this preparation it appeared that the response to $10^{-4} \mathrm{gm} / \mathrm{ml}$. of larval food matched rather closely the response to $10^{-\top} \mathrm{gm} / \mathrm{ml}$. of acetylcholine chloride . According to this, one may calculate the amount of acetylcholine like substance recovered from the dried larval food as equivalent to $1 \mathrm{mg}$. of acetylcholine chloride/gm. of larval food. Assays of samples 
of fresh larval food were made on three preparations of Bufo muscle and equivalents of 1 to $2 \mathrm{mg}$. acetylcholine chloride per milliliter of larval food were found.

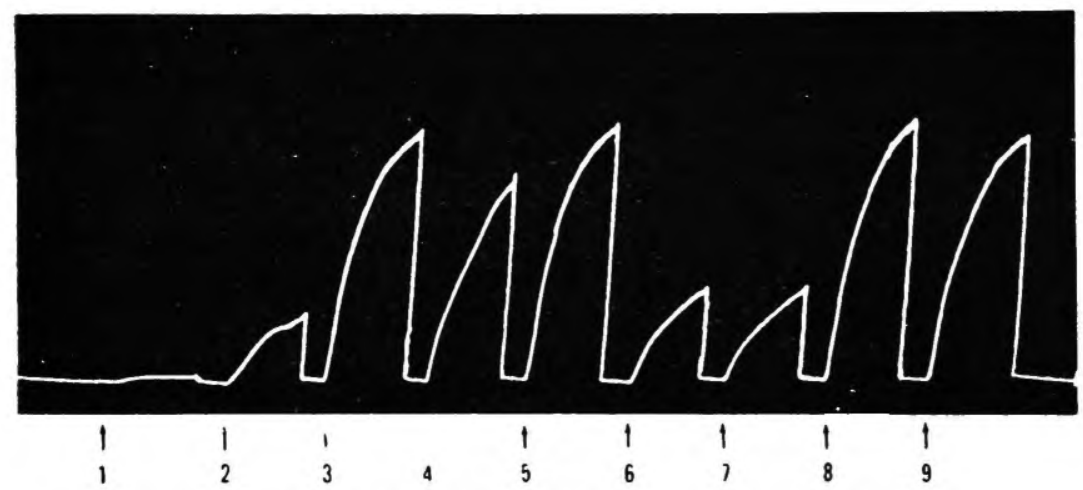

FIG. 2. Assay of dried larval food against acetylcholine on isolated rectus abdominis muscle of Bufo ictericus.
1) Larval food
2) " "
3) " "
4) " "
5) Acetylcholine chloria
7) Larval food
8) ", "
9) Acetylcholine chloride

\begin{tabular}{|c|c|c|c|}
\hline \multicolumn{4}{|c|}{$10^{-8} \mathrm{gm} . / \mathrm{ml}}$. \\
\hline & $10-5$ & " & \\
\hline & $10^{-4}$ & $"$ & , \\
\hline $5 x$ & $10^{-5}$ & $"$ & \\
\hline & $10^{-7}$ & $"$ & $n$ \\
\hline & $10^{--8}$ & $"$ & $"$ \\
\hline & $10^{-5}$ & $"$ & $"$ \\
\hline & $10-4$ & $"$ & $"$ \\
\hline & $10^{-7}$ & $"$ & \\
\hline
\end{tabular}

The longitudinal body muscles of Holothuria grisea were also used to help identify and quantitate the acetylcholine-like material in the larval food. In addition to a high sensitivity to acetylcholine, one of the more useful properties of the $H$. grisea muscle is its very rapid relaxation, and recovery of sensitivity, following the washing out of the test solution.

The record reproduced in Fig. 3 has been chosen to illustrate three points. First, it shows that $10^{-4} \mathrm{gm}$./ml. of fresh larval food produces a contraction (test 3 ) only slightly less than $10^{-7}$ acetylcholine (test 1) Second, that larval food maintained at $4^{\circ} \mathrm{C}$. for 70 days has an activity equal to that of freshly collected larval food (cf. tests 3 and 4) Third, that benzoquinonium blocks or reduces the actions of larval food and acetylcholine on this preparation. In 
Fig. 3, it would appear that tests 5 and 6 gave nearly equivalent responses. The response to $10^{-5}$ acetylcholine was probably maximal for this muscle and an equivalent shortening of the muscle might have been produced by a lesser amount of acetylcholine.

Three additional assays of fresh larval food, each on a different muscle preparation of $H$. grisea, gave acetylcholine equivalents close to $1 \mathrm{mg}$./gm. of larval food.

Assays of dried larval food, done at Harvard University on the isolated Venus heart, also indicated an acetylcholine activity equivalent to about $1 \mathrm{mg}$./gm. of larval food. All three assay preparations, therefore, indicated approximately the same level of acetylcholine activity in fresh, refrigerated, and dried samples of larval food of Melipona quadrifasciata. Clearly, there is little, if any, loss of activity in the larval food after refrigeration for a period of 70 days or after drying and redissolving.

Since equivalent dilutions of larval food and acetylcholine standards produced equivalent response ${ }_{S}$ on three different assay preparations, and both larval food and acetylcholine actions were potentiated by physostigmine and blocked by benzoquinonium, this provides strong presumptive evidence that acetylcholine is present in the larval food of Melipona quadrifasciata.

\section{b) Chromatography of larval food:}

The presence of acetylcholine in larval food was confirmed by chromatography First, the freshly collected, liquid larval food was spotted on paper in various amounts, with acetylcholine and choline for reference. After development in butanol - acetic acid - water, the dried chromatograms were examined under ultra-violet light and then dipped in Dragendorf's reagent. Fig. 4 is a tracing of a chromatogram showing the areas that reacted with Dragendorf's. The larval food gave two spots; one with an Rf corresponding to acetylcholine: the other to choline. Areas showing a blue fluorescence and giving an orange - yellow color with Dragendorf's surrounded the points of origin of the larval food (but compare Fig. 6) 

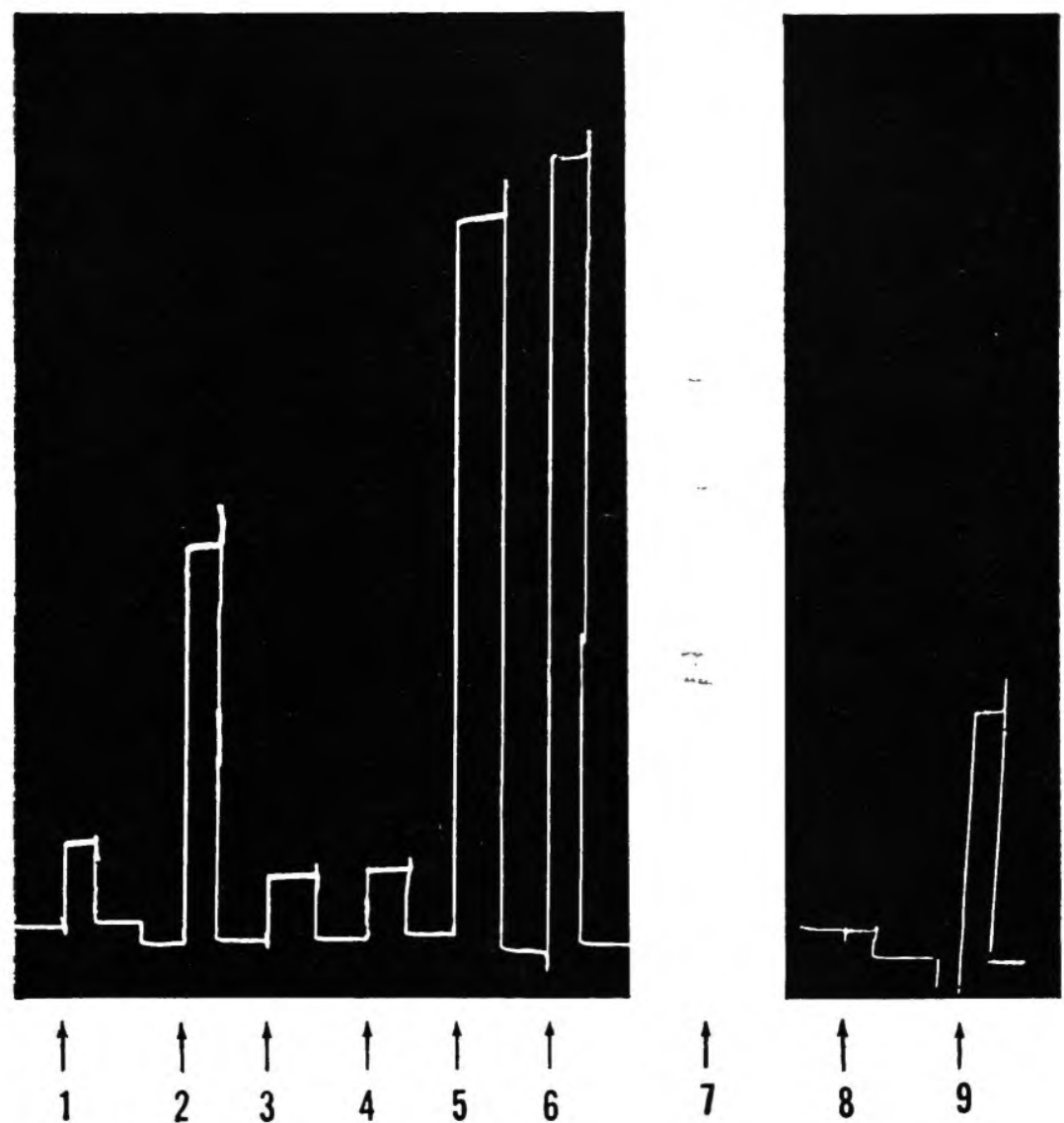

FIG. 3. Comparison of acetylcholine activity of fresh larval food of $M$. quadrifasciata with larval food refrigerated for 70 days on logitudinal muscle of $H$. grisea.

Record also shows the blocking action of benzoquinonium. Each application was for $1 \mathrm{~min}$. with drum stopped. Drum then moved manually to new position and bath flushed with sea water.
1) Acetylcholine chloride
2) " "
3) Fresh larval food
4) Refrigerated larval food
5) Fresh larval food
6) Acetylcholine chloride
7) Benzoquinonium
8) Fresh larval focd
9) Acetylcholine chlcride

\begin{tabular}{|c|c|c|}
\hline $0-7$ & m. & $/ \mathrm{ml}$ \\
\hline $10-6$ & & \\
\hline $10-4$ & $"$ & \\
\hline $10-4$ & $"$ & \\
\hline $10-3$ & " & \\
\hline $10-5$ & $"$ & \\
\hline $10-4$ & $"$ & \\
\hline $10-4$ & $"$ & \\
\hline $10-5$ & $"$ & \\
\hline
\end{tabular}




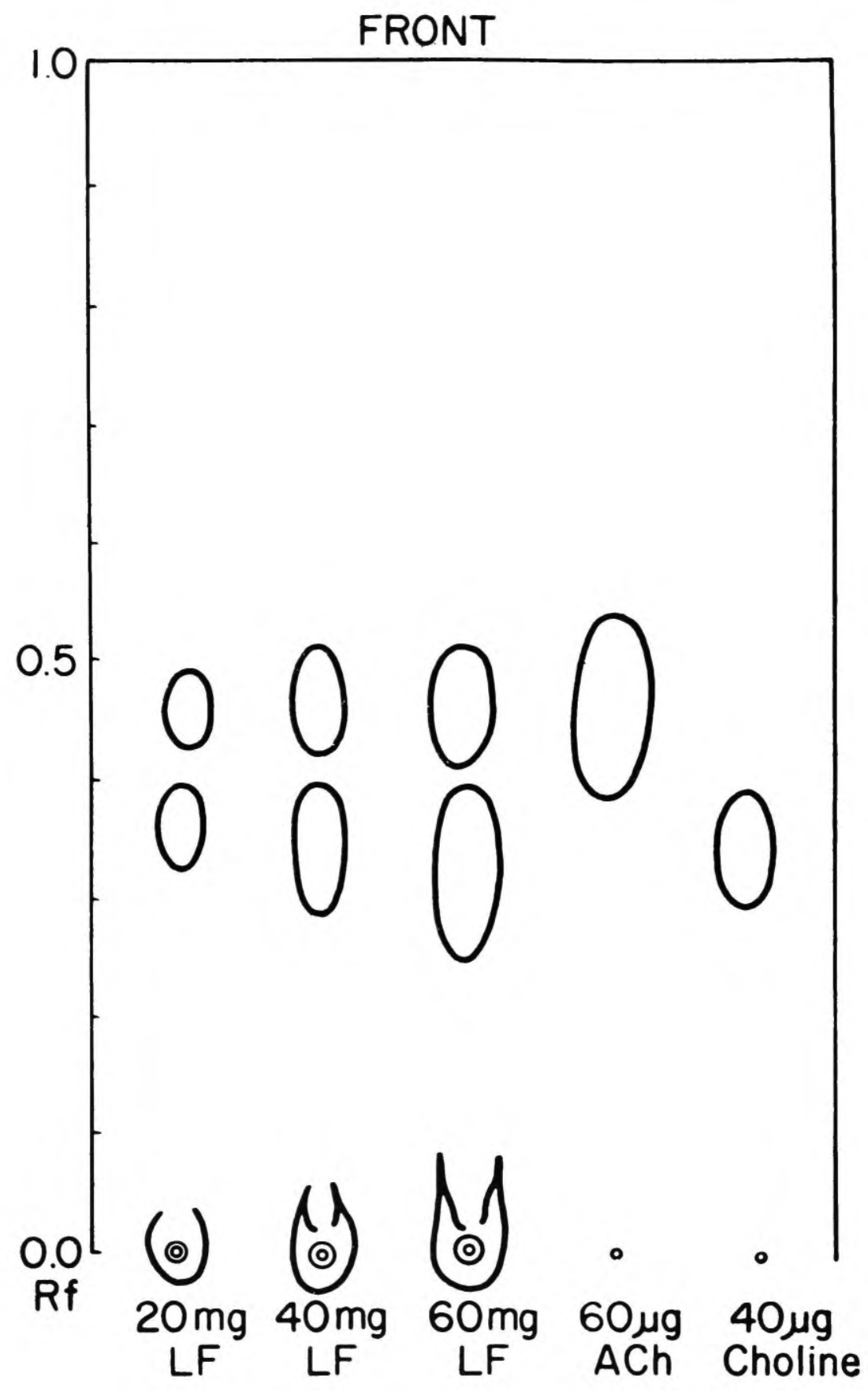

FIG. 4. Tracing of a chromatogram of fresh larval food (LF) of M. quadrifasciata, with acetylcholine ( $\mathrm{ACh}$ ) and choline standards. This and the following chromatograms were developed for $12 \mathrm{hrs}$. in n-butanolacetic acid-water. Spots reacting with Dragendorf's reagent have been outlined. Areas around origins of larval food were orange - yellow in color (c.f. Fig. 5). 
The areas outlined in Fig. 4 permit a rough estimate of the acetylcholine and choline content of the larval food. Since $60 \mu \mathrm{g}$. of acetylcholine chloride produced an area about twice as large as 60 mg. of larval food, this would indicate an acetylcholine content of about $0.5 \mathrm{mg} . / \mathrm{ml}$. of fresh larval food. The area covered by $40 \mu \mathrm{g}$. of choline is approximately equal to that of the spot with the same Rf value derived from $40 \mathrm{mg}$. of larval food. This would indicate a choline content of about $1 \mathrm{mg} . / \mathrm{ml}$. of larval food.

When a sample of larval food from a different colony of Melipona quadrifasciata was subjected to chromatography, areas corresponding in $\mathbf{R f}$ values to choline and acetylcholine were found (Fig. 5 ) and the amounts approximated those mentioned above. Also, the same area was found surrounding the points of application of the larval food. In addition, however, prominent Dragendorf reacting spots were found just below the choline spots. These had a characteristic color and an $\mathrm{Rf}$ value corresponding to glycine betaine but, since a sample of known glycine betaine was not run with this chromatogram, the identification must be considered as tentative. It is important, nevertheless, to know that the quaternary base composition of larval food of Melipona may differ from colony to colony or, perhaps, from time to time in a given colony

\section{c) Chromatography of extracts of larval food.}

A sample of larval food from colony 1 was dried under reduced pressure and stored with anhydrous $\mathrm{CaCl}_{2}$. A portion weighing 850 mg. was extracted with $3 \mathrm{ml}$. of $95 \%$ ethanol. The extract was evaporated to dryness and taken up in $4.0 \mathrm{ml}$. of $95 \%$ ethanol. In one instance an amount of larval food extract (LFE) derived from 30 mg. of dry larval food was spotted on paper and run with acetylcholine as a reference. Development and location of spots were the same as for chromatograms of fresh larval food. Fig. 6 is a tracing of the resulting chromatogram. Again, spots with $\mathrm{Rf}$ value $\mathrm{S}$ corresponding with acetylcholine and choline are seen. Where acetylcholine was combined with LFE it summed with the acetylcholine of the extract. The area of the spot produced by an extract of $30 \mathrm{mg}$. of dried larval food is somewhat greater than that produced by $20 \mu \mathrm{g}$ 
FRUIVT

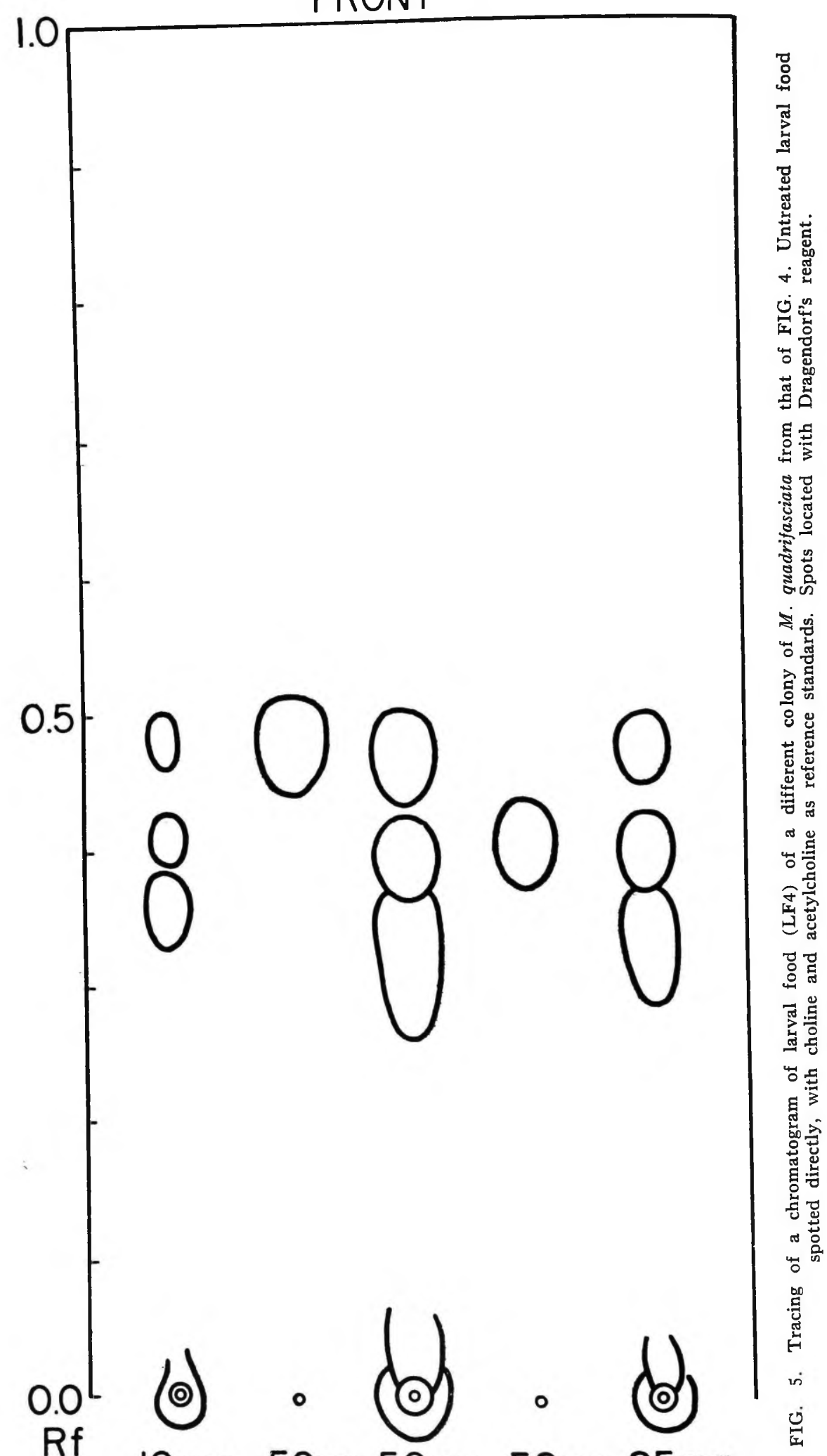

$10 \mathrm{mg} 50 \mu \mathrm{g} 50 \mathrm{mg} 50 \mu \mathrm{g} 25 \mathrm{mg}$ IF4 ACh LF4 Choline LF4 


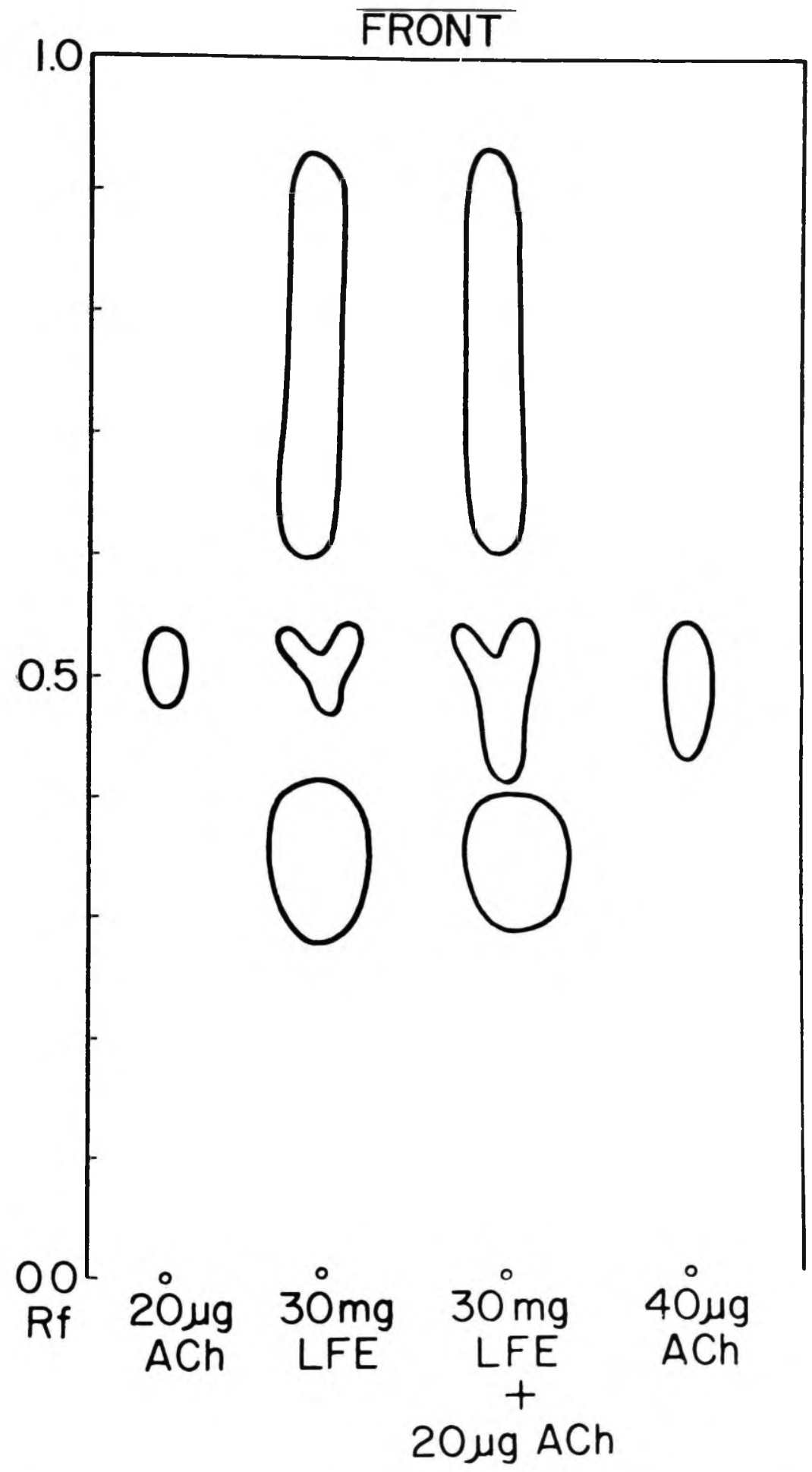

FIG. 6. Tracing of a chromatogram of an ethanol extract of dried larval food (LFE) of $M$. quadrifasciata. The ethanol soluble material from 30 mg. of larval food was spotted. Acetylcholine was run as a reference standard and also spotted with one sample of LFE. Spots located with Dragendorf's reagent. 
of acetylcholine. This indicates that this sample contained about 1 mg. acetylcholine/gm. dried larval food.

The large, fast-running areas shown in Fig. 6 gave a blue fluorescence under ultra-violet light and reacted with Dragendorf's reagent to give an organge-yellow color. No similarly colored areas remained around the points at which the extract of larval food had been applied. Clearly, there is a component of larval food that fails to run in butanol - acetic acid - water when fresh larval food is spotted, but which is extracted by ethanol and then runs in the same solvent system with a high Rf value. Its reaction with Dragendorf's reagent suggests that it might be a quaternary amine. Attempts to learn more concerning the nature of this material are discussed in the next section.

d) Chromatography, elution, and assay

With the chromatographic evidence that a quaternary ammonium base other than choline, acetylcholine and glycine betaine might be present in ethanol extracts of dry larval food, it was of interest to know if it might contribute to the acetylcholine-like activity of such extracts. Accordingly, an ethanol extract of $500 \mathrm{mg}$. of dried larval food was streaked on Whatman $3 \mathrm{MM}$ paper and the paper developed in butanol - acetic acid - water A strip was cut from one side of the paper and dipped in Dragendorf's reagent in order to determine the location of the fast-running and acetylcholine areas. Horizontal strips were then cut from the paper to include the fast-running material (Strip I) and the acetylcholine area (Strip II) Each strip was eluted in $10 \mathrm{ml}$. of sea water, and the eluates compared with one another and with acetylcholine on two different muscle preparations from $H$. grisea. Fig. 7 A \& B are portions of the records. When the eluate of strip II was diluted until the final concentration in the bath was $1: 10,000$, the response of record $\mathrm{Al}$ was obtained. This was matched by $10^{-8} \mathrm{gm}$. acetylcholine $/ \mathrm{ml}$. of bathing fluid. The eluate of strip I produced a muscle contraction as seen at A4 and 7 A match was not obtained with either the eluate of strip II or with acetylcholine. In record $B$, the response at test 4 is to a 1:100 dilution of the material from strip $I$ and it is very nearly matched at test 5 by a $1: 10,000$ dilution of the material from strip II . 

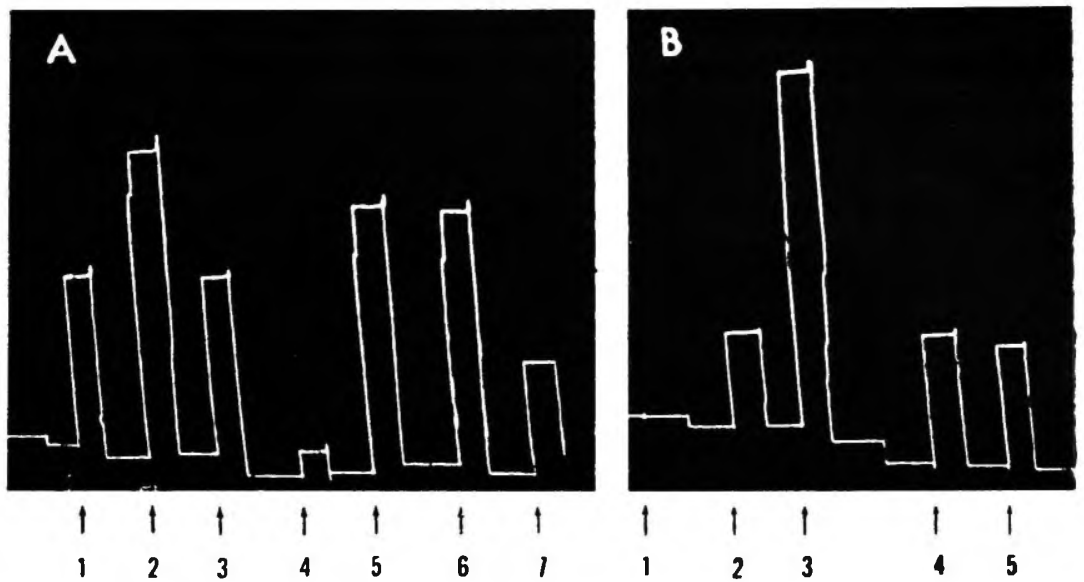

FIG. 7. Tests cn tivo muscles of $H$. grisea of eluates of chromatogram of esthanol extract of $500 \mathrm{mg}$. dried larval food of $M$. quadrifasciata. Strip I = upper, unidentified substance. Strip II $=$ acetylcholine area . Activities compared with acetylcholine. Duration of each test $=1 \mathrm{~min}$. with stationery drum; drum then turned manually; bath flushed several times with sea water, and drum again turned before next test.

\section{RECORD A}

1) Strip II eluate

2) Acetylcholine chloride

3) Acetylcholine chloride

4) Strip I eluate

$1: 10,000$ in bath

$2 \times 10^{-8} \mathrm{gm} . / \mathrm{ml}$.

$10-8 \mathrm{gm} . / \mathrm{ml}$.

5) Strip I eluate $1: 1000+\mathrm{A} \mathrm{CH} 10-8 \mathrm{gm} . / \mathrm{ml}$.

7) Strip I eluate

$1: 200$ in bath

\section{RECORD B}

1) Acetylcholine chloride

2) " " "

3)

4) Strip I

5) Strip II

$$
\begin{aligned}
& 10^{-9} \mathrm{gm} . / \mathrm{ml} . \\
& 10^{-8} " \Rightarrow " \\
& 10^{-7} " \Rightarrow " \\
& 1: 100 \text { in bath } \\
& 1: 10,000 \text { in bath }
\end{aligned}
$$

The material from strip II, near Rf 0.5 , almost certainly is acetylcholine. The muscle of $H$. grisea relaxed more slowly on washing out the eluate of strip I than it did after tests of the eluate of strip II, or of acetylcholine standards. Since the fast-running material also appeared on chromatograms of pollen stored by Melipone quadrifasciata it will be referred to again in section 3 . 
2. Acetylcholine in honey.

Several investigators have reported the presence of acetylcholine in honey of Apis mellifera (e. g. Marquardt, Ahring and Vogg, 1953; Watanabe, 1955) The amounts reported in honey are much less than those in larval food of the honey bee as they range from only 0.02 to $5 \mu \mathrm{g}$. $/ \mathrm{gm}$. honey

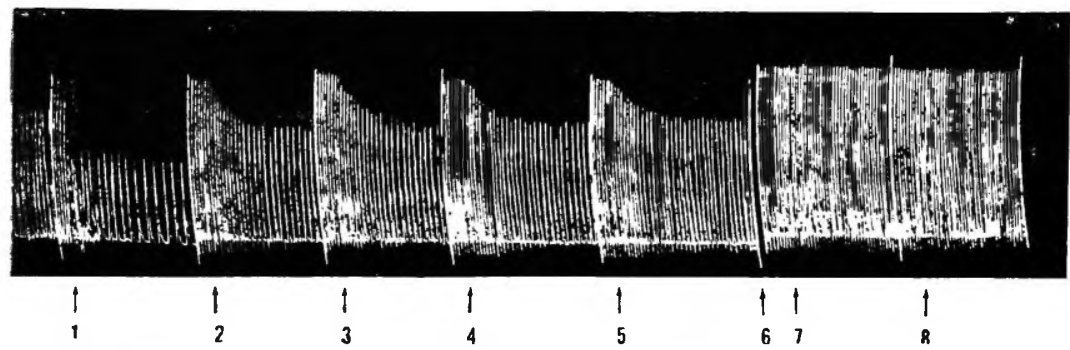

FIG. 8. Assay for acetylcholine in honey of $M$. quadrifasciata using the isolated ventricle of the heart of Venus mercenaria.
1) Acetylcholine chloride
2) Honey
$10^{-9} \mathrm{gm} . / \mathrm{ml}$.
3) Acetylcholine chloride
4) Honey
5) Acetylcholine chloride
6) Benzoquinonium
7) Honey

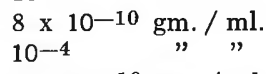
$8 \times 10-10 \mathrm{gm} . / \mathrm{ml}$.
$10-5$
$10-4$
$"$,
8) Acetylcholine chloride
$8 \times 10^{-10} \mathrm{gm} . / \mathrm{ml}$.

Benzoquinonium again added to bath between tests 7 and 8 .

A sample of honey of $M$. quadrifasciata was assayed on the isolated Venus heart. The honey, diluted with sea water, had an action on the heart that was indistinguishable from that of the acetylcholine standard (Fig. 8) After benzoquinonium, the depressor actions of the honey and acetylcholine were completely blocked. In assays on three separate hearts this sample of honey gave an average value, in acetylcholine chloride equivalents, of $8 \mu \mathrm{g} . / \mathrm{gm}$. honey . This is roughly $1 / 100$ of the amount found in larval food of Melipona quadrifasciata.

3. Acetylcholine in stored pollen.

It was of interest to learn if acetylcholine, or choline, might be found in the stored pollen of this stingless bee. Large amounts of 
pollen are stored in pots near the brood cells. When not being used by the bees, the pollen pots are sealed with wax. This maintains the pollen in a moist, pasty condition until it is required as food for the colony

Several samples of pollen were removed from different colonies of $M$. quadrifasciata. After drying, suitable amounts were extracted with ethanol. Usually the sample of pollen was thoroughly ground in a glass homogenizer during the extraction. After storing at a low temperature for 24 hours, and filtering, the ethanol extract was evaporated to dryness, the residue washed with petroleum ether. and dissolved in $70 \%$ ethanol or $50 \%$ acetone for spotting on paper. Chromatograms were run in a variety of solvents, and several methods have been used in an effort to identify some of the components

A tracing of a chromatogram that was developed in butanol acetic acid - water and dipped in Dragendorf's reagent is shown in Fig. 9. Acetylcholine was the only reference standard that was used in this chromatogram. The pollen extract gave a spot with an $\mathbf{R f}$ value and color reaction identical with acetylcholine. An amount of extract derived from $5 \mathrm{mg}$. of pollen gave a spot with an area approximately equal to $20 \mu \mathrm{g}$. of acetylcholine chloride. From this one may calculate that one gram of this sample of stored pollen contained roughly $4 \mathrm{mg}$. of acetylcholine. Other samples of stored pollen yielded less than this amount.

The lowest spots shown in Fig. 9 almost certainly are choline spots, although no choline standard was run on this chromatogram. The fast-running material showed all of the features seen in the fastrunning material from ethanol extracts of larval food.

Extracts of two samples of stored pollen, when subjected to chromatography, gave an additional spot with Dragendorf's reagent having the characteristics of glycine betaine.

Two extracts were streaked on paper, the chromatograms developed and dried, and horizontal strips cut, eluted and the eluates tested on the Venus heart. The strips with, by far, the greatest acetylcholine-like activity lay between $\mathrm{Rf} 0.45$ and 0.55 . 


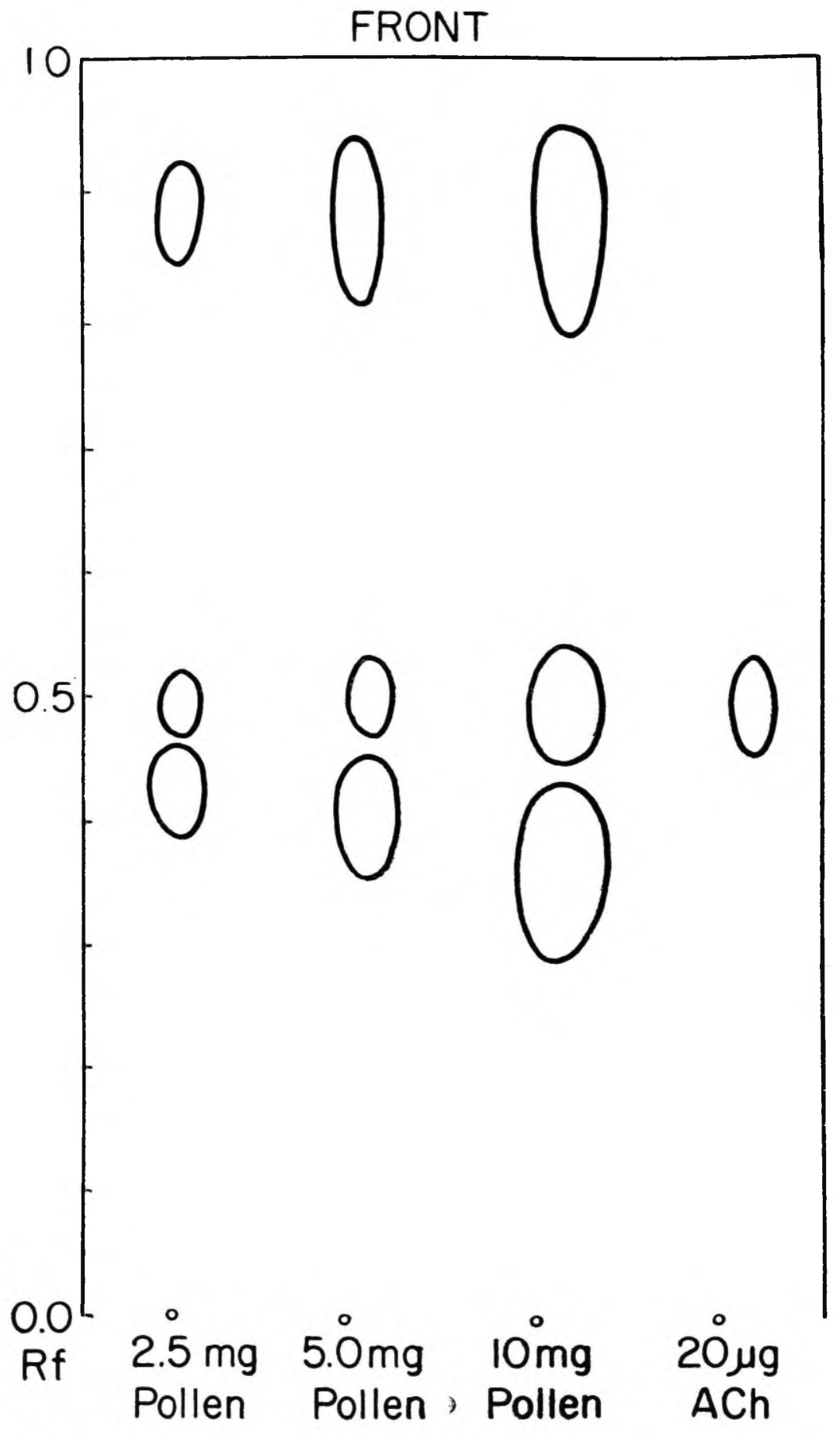

FIG. $\dddot{y}$. Tracing of chromatogram of ethanol extract of dried, hive pollen of $M$. quadrifasciata. Spots located with Dragendorf's reagent. 
4. Choline and related compounds from anthers and pollen.

It was next of interest to know if acetylcholine and choline are to be found in pollens that have not been collected by Melipona and, therefore, have not been mixed with substances that might have originated in the bee. Obviously the bees must have some choline source, since it is a nutritional requirement of insects, but the bees might acetylate choline and transfer acetylcholine, through secretions, both to the larval food and the stored pollen.

During the limited time that we worked together in Brazil, it was possible to examine only the mature anthers of two flowering plants: Hybiscus and a large composite (Montana grandiflora DC) These were collected, dried, and extracted with ethanol. The extracts were spotted with acetylcholine as a standard. After developing in butanol - acetic acid - water the hybiscus extract gave two spots that reacted with Dragendorf's reagent. One spot had an $\mathrm{Rf}$ value close to acetylcholine, the other close to choline (Fig. 10) The extract of anthers of the composite gave only one spot with an Rf value corresponding to the choline standards run on other chromatograms that had been processed in a similar manner (Fig. 10)

One of us (J. H. W.) has since run chromatograms of a number of known pollens of northern trees and herbaceous plants. All have yielded a component that has the characteristics of choline. This is sometimes present in large amounts (up to $5 \mathrm{mg} . / \mathrm{gm}$.) Some have shown smaller amounts of an acetylcholine-like component, and, in addition, some pollens have yielded a substance that is probably glycine betaine. Pollens would seem to be rich sources of these methylated, quaternary ammonium bases.

It seems highly probable that the quaternary bases found in stored pollen of Melipona quadrifasciata that we believe to be choline, acetylcholine, glycine betaine, and an unidentified base were present in the pollens when they were collected by the bees. Pollens of all plant species may not contain the same relative amounts of these bases and this might account for our failure to detect glycine betaine in all samples of stored pollen.

The question that has been asked by those investigators who have been concerned with the origin of the large amount of acetyl- 


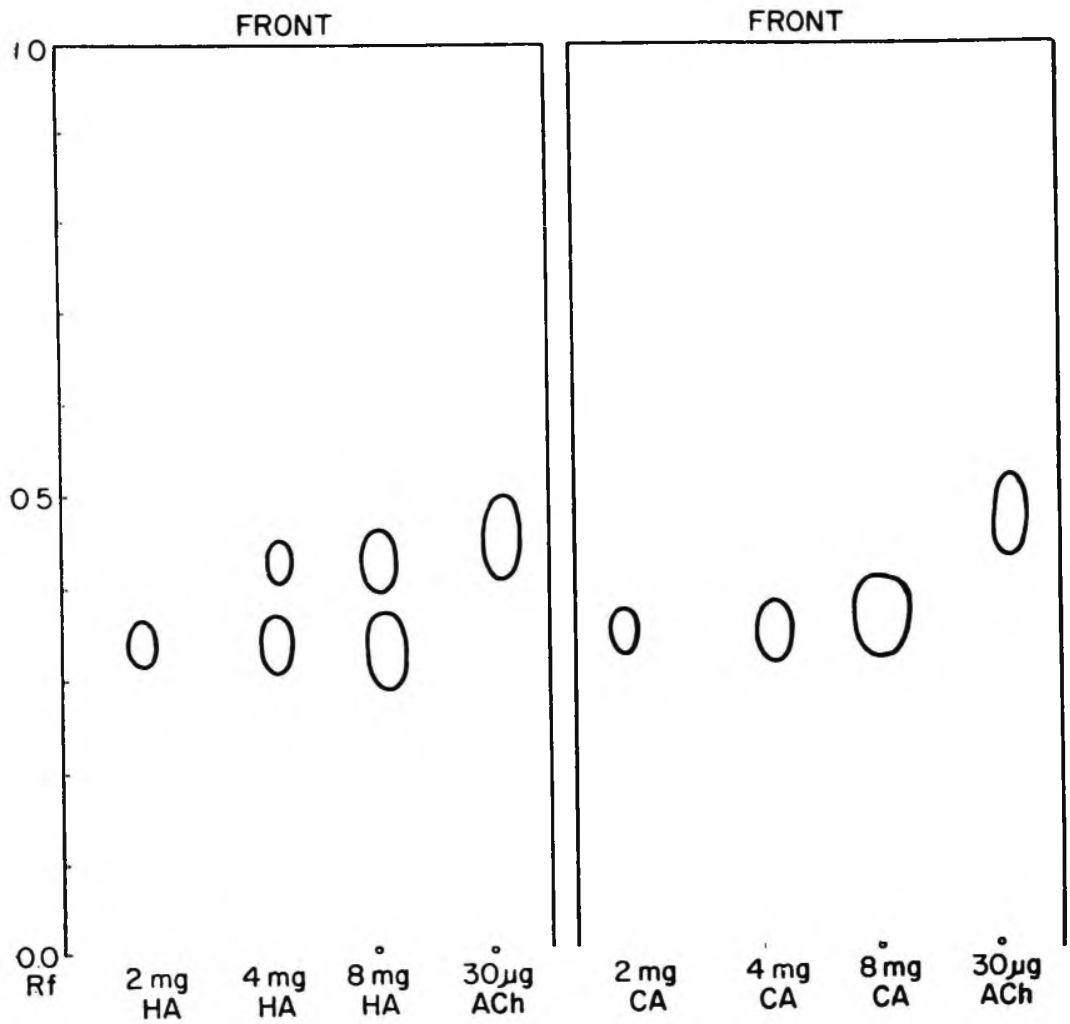

FIG. 10. Tracings of chromatograms of ethanol extracts of dried anthers of hybiscus (HA) on left and of a composite (CA) on right. Spots located with Dragendorf's reagent. Developed at a lower temperature than were other chromatograms.

choline in the larval food of Apis mellifera (e. g. Colhoun and Smith, 1960) also applies to Melipona quadrifasciata. There would appear to be at least two possibe answers; either the acetylcholine originates in the pollen and is concentrated by the bees and transferred to the larval food, or the bees obtain choline from the pollen, acetylate it somewhere in their bodies, and transfer the acetylcholine to the larval food. In the time available, we were only able to start some experiments that might have provided an answer. 


\section{Acetylcholine content of parts of Melipona quadrifasciata}

Certain head glands of Apis mellifera secrete some of the constituents of the royal jelly that is fed the queen, as well as the food that is fed to the queen larvae and, in part to worker and drone larvae (Hoffmann, 1960) However, Colhoun and Smith (1960) could obtain no synthesis of acetylcholine when homogenates of the hypopharyngeal and post-cerebral glands of the honey bee were used as possible sources of choline acetylase. They did obtain a high rate of synthesis by brain tissue and insect nervous systems generally contain high levels of acetylcholine. It seems unlikely, though, that acetylcholine synthesized in the nervous system of Apis or Melipona could be transferred to the larval food. The possibility remains that these insects may synthesize, or conserve and concentrate, acetylcholine in some other region of the body This is made plausible by the discovery of very large amounts of acetlcholine in the venom of the hornet, Vespa crabro, (Bhoola, Calle and Schachter, 1961), in the silk gland of the caterpillar of the tiger moth, Arctia caja (Morley and Schachter, 1961), and in the reproductive organs of this, and certain other moths (Morley and Schachter, 1962)

As a first step toward locating a region, other than the nervous system, where $M$. quadrifasciata might synthesize or concentrate acetylcholine, we estimated the levels of acetylcholine in the head, thorax and abdomen of two lots of bees. One lot consisted of 15 young adults that were removed from a colony. They were chloroformed, rinsed with distilled water and blotted dry. After removing the wings, the bodies were divided into head, thorax and abdomen. The pooled parts were weighed and dropped into $3 \mathrm{ml}$. of water heated to $100^{\circ} \mathrm{C}$ and allowed to remain for $5 \mathrm{~min}$. They were then ground finely in a glass homogenizer and, after suitable dilutions with sea water, were assayed for their acetylcholine content on two different muscle preparations of $H$. grisea. A record of one of these assays is shown in Fig. 11. From these assays we estimated that the heads contained an equivalent of 4 to $5 \mu \mathrm{g}$. of acetylcholine/gm. of fresh tissue; the thorax contained 2.5 to $3.5 \mu \mathrm{g}$. $/ \mathrm{gm}$; while the abdomens contained more than $100 \mu \mathrm{g} . / \mathrm{gm}$. 


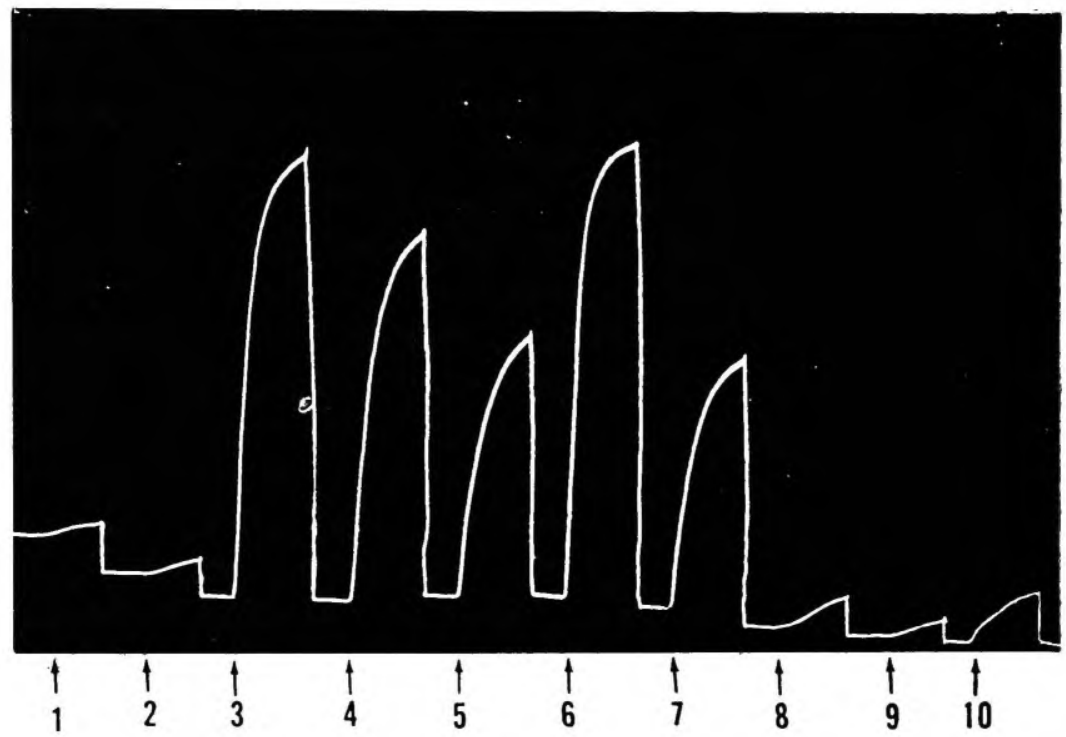

FIG. 11. Record of assay of head, thorax and abdomen of $M$. quadrifasciata, using isolated longitudinal muscle of $H$. grisea. Kymograph drum allowed to turn during a test but stopped during the period of washing.
1) Head
2) Thorax
3) Abdomen
4) "
5) "
6) Acetylcholine chloride
7) " "
8) Head
9) Thorax
10) Acetylcholine chloride
$2.0 \mathrm{mg} . / \mathrm{mI}$.
$3.2 " "$
$3.6 " "$
$1.8 "$ "
$0.9 " \prime$
10-6 $\mathrm{gm} . / \mathrm{ml}$
10-7" "
$3.0 \mathrm{mg} . / \mathrm{ml}$
$4.0 "$,
$10^{-8} \mathrm{gm} . / \mathrm{ml}$.

Twenty adult bees caught by net while flying near the hive were treated in a similar manner. Heads and thoraces yielded about equal amounts of acetylcholine and the abdomens several times as much, but exact matches with the acetylcholine standards were not made. There was no time for further experiments.

Clearly there is much more acetylcholine in the abdomen of adult $M$. quadrifasciata than in the remainder of the body, but we do not know whether it derives from food remaining in the digestive tract or from other sources. This is a promising lead that should be 
followed in further studies on stingless bees as well as with the honeybee. Should it develop that the apparent high acetylcholine level of the abdomen was derived from food, there would remin the question of the survival, during the digestive process, of such an easily hy. drolyzed molecule as that of acetylcholine. Also, there would remain the question of the mode of concentration and transfer, by nurse bees, to the larval food.

6. $\mathrm{pH}$ of larval food and honey

One further observation should be mentioned. Royal jelly of the honeybee has a pH between 3.9 and 4.1 (Colhoun and Smith, 1960) Acetylcholine is most stable at $\mathrm{pH} 3.9$ While precise measurements were not made, tests with $\mathrm{pH}$ parers showed samples of larval food to be close to $\mathrm{pH} 4$. This is another remarkable feature in common with larval food of the honeybee.

Honey of this species had earlier been found to have a $\mathrm{pH}$ of 4.1 (Nogueira Neto, 1953) The stored pollen of this bee had a $\mathrm{pH}$ of 2.95 in samples examined by the Inst. de Pesquisas Tecnológicas of S. Paulo.

\section{DISCUSSION}

By means of biossays, the use of a selective blocking agent, and chromatography, acetylcholine has been identified in the larval food, honey, and stored pollen of Melipona quadrifasciata. The values in equivalents of acetylcholine chloride, found for different sample $\mathrm{s}$ of larval food range from 0.5 to $2.0 \mathrm{mg}$. $/ \mathrm{gm}$. These values are very close to those reported for royal jelly of Apis mellifera by various investigators (e. g. Watanabe, 1955; Henschler, 1956; Jacoli, 1956; Colhoun and Smith, 1960) They also correspond closely with the amounts found by Henschler and von Rhein (1960) in food of worker larvae of Apis $(0.73$ and $11 \mathrm{mg}$. acetylcholine, free base, per gram dry larval food), and of drone larvae (1.65 and $1.8 \mathrm{mg} . /$ gm.) The value of $71 \mathrm{mg}$./gm. for the food of small worker larvae, as originally reported by Henschler and von Rhein, was a printing error and the correction to $11 \mathrm{mg}$./gm. was later made.*

* Die Naturwissenschafter 47, p. 456, 1960. 
A much smaller amount ( $8 \mu \mathrm{g} . / \mathrm{gm}$.) of acetylcholine has been found by us in a sample of honey of Melipona. This is somewhat higher than has been found in samples of Apis honey (see Henschler, 1954, for early references; also Goldschmidt and Burkert, 1955; Watanabe, 1955)

In seeking the source of the large amount of acetylcholine in the larval food of Melipona, we assumed that it would have the same origin as in the larval food of the honeybee. Colhoun and Smith (1960) had shown that an extract of the head glands of nurse worker honeybees (the source of royal jelly) did not synthesize acetylcholine when all conditions for demonstrating choline acetylation had been met. With the same procedure he found that bee brain tissue synthesized up to $50 \mathrm{mg}$. acetylcholine per gram per hour We, therefore, dismissed the possibility that Melipona might synthesize acetylcholine in its head glands and sought some other source.

Since honey and stored pollen ("bee bread") are the foods of Apis and Melipona, choline, at least, must derive from one of these sources because it is a nutritional requirement of insects. Pollen appeared to be the more likely source of this compound. By means of chromatography, choline was readily identified in extracts of stored pollen of Melipona quadrifasciata, in the anthers of two flowers (Hybiscus and Montañoa grandiflora), and in several pollens of other flowering trees and plants. It occurs in amounts up to 5 $\mathrm{mg}$./gm. of pollen in some species. In addition, and quite unexpected, we also found acetylcholine in stored pollen; in one sample about 4 $\mathrm{mg}$./gm. It has also been found in some of the hand collected pollens that have been subjected to chromatographic analysis and bioassay Clearly, pollen could be the source of the acetylcholine of the larval food but it would have to be conserved, concentrated, and transferred to the larval food by the nurse bees. There is indirect evidence that this may be done.

In addition to acetylcholine, all samples of larval food of $\mathrm{Me}$ lipona that were subjected to chromatography were shown to contain choline. All samples also yielded a substance that failed to run in butanol-acetic acid-water when fresh larval food was spotted but which ran with a high $\mathrm{Rf}$ value when ethanol extracts of dried larval food were similarly subjected to chromatography This substance 
was not identified but it had the following properties: spots had a blue fluorescence under ultra-violet light; were orange yellow after treatment with Dragendorf's reagent; when eluted and assayed, the eluate acted much like acetylcholine. Chromatograms of ethanol extracts of stored pollen always yielded spots with a high $\mathrm{Rf}$ value, and other characteristics, similar to this fast running material from larval food. However, this unidentified substance was more concentrated in the larval food than in the stored pollen.

Chromatograms of one sample of larval food (Fig. 5) gave a spot with an $\mathrm{Rf}$ value of 0.35 and a slowly developing red color with Dragendorf's reagent. These are characteristic of glycine betaine. Some samples of stored pollen, as well as some hand-collected pollens, upon extraction and chromatography, showed the presence of a substance that appears to be identical with glycine betaine.

The important point we wish to emphasize is that acetylcholine, choline, glycine betaine and an unidentified compound (all reacting with Dragendorf's reagent) that we have found in the larval food of Melipona quadrifasciata also were found in samples of stored pollen. Furthermore, these same substances have been found in hand-collected samples of pollen where they could not have been added by the bees. It would appear that Melipona quadrifasciata, in some way, transfers these substances (and possibly others) from pollens to the larval food. The acetylcholine found in their honey could be similarly transferred. The manner in which this is done, however, remains obscure The presence of a much larger amount of acetylcholine in the abdomen of Melipona quadrifasciata than in head or thorax suggests two possibilities: either it is located in certain nonnervous structures such as certain glands (cf. Morley and Schachter, 1961,1962 ), or it is present in the contents of the digestive tract. It seems most unlikely that glands would concentrate a series of quaternary bases, therefore we favor the view that acetylcholine and the other bases are extracted from the pollen in the course of its digestion, then concentrated and transferred, to the larval food. This might be a means of providing only the required choline, although it is conceivable that acetylcholine plays some specific role in larval growth as suggested by Colhoun and Smith (1960) for the honeybee. 


\section{RESUMO}

1) Com o emprêgo de diversos métodos, verificou-se que o alimento da larva Melipona quadrifasciata contêm quantidades de acetilcolina equivalentes entre 0,5 e $2,0 \mathrm{mg}$ de cloreto de acetilcolina por grama de alimento. Quantidades semelhantes foram registradas no alimento da larva de abelha Apis mellifera.

2) No alimento da larva de $M$. quadrifasciata há também grande quantidade de colina e de uma substância não identificada, solúvel em etanol, que deu fluorescência azul, reagiu com o reativo de Dradendorf, e tinha fraca ação acetilcolínica. Em uma amostra de alimento da larva, encontrou-se uma substância com propriedades da glicina-betaina.

3) Nas amostras de polen armazenado também existe acetilcolina, colina e a substância não identificada.

4) Uma amostra de mel de $M$. quadrifasciata possuia $8 \mu \mathrm{g}$ de acetilcolina por gr de mel.

5) Em dois lotes de $M$. quadrifasciata adultas verificou-se haver muito mais acetilcolina no abdomem que na cabeça ou no tórax.

6) Notou-se ainda que nas anteras e no polen de diversas espécies de plantas ocorre colina. Algumas possuem também acetilcolina e glicina-betaina, enquanto que em tôdas existe o material não identificado de fluorescência azul.

7) Sugeriu-se que a acetilcolina e outras bases quaternárias achadas no alimento larvar de $\boldsymbol{M}$. quadrifasciata são derivadas de polens de que as abelhas se alimentam; que elas são conservadas e concentradas no trato digestivo e transferidas pelas abelhas criadoras para o alimento larvar. 
If acetylcholine does not have some specific role, it is a strange coincidence that the $\mathrm{pH}$ of larval food and honey of both Melipona quadrifasciata and Apis mellifera is within the range at which it is most stable, and that it may be recovered from these substances after their storage for months and even years.

Further observations on stingless bees and Apis will be necessary to test the suggestion $\mathrm{S}$ that we offer. Quite possibly, there is information on the honeybee, of which we are not aware, that would help to confirm or deny the hypothesis that we offer, since it is reasonable to assume similar sources for the acetylcholine of the larval foods of the two groups of bees.

\section{SUMMARY}

1) Using several methods, the larval food of Melipona quadrifasciata was found to contain amounts of acetylcholine estimated to range between 0.5 and $2.0 \mathrm{mg}$. equivalents of acetylcholine chloride per gram of larval food. Similar amounts have been reported for the larval food of the honey bee, Apis mellifera.

2) The larval food of $\boldsymbol{M}$. quadrifasciata was also found to contain a large amount of choline and an unidentified substance that was soluble in ethanol, gave a blue fluorescence, reacted with Dragendorf's reagent, and had a weak acetylcholine-like action. In one sample of larval food, a substance with the properties of glycine betaine was also found.

3) Samples of stored pollen were also found to contain acetylcholine, choline and the unidentified substance.

4) One sample of $M$. quadrifasciata honey contained $8 \mu \mathrm{g}$. of acetylcholine per gram of honey.

5) In two lots of adult $M$. quadrifasciata, much more acetylcholine was found in abdomens than in heads or thoraces.

6) Anthers and pollen of several species of trees and plants have all been found to contain choline. Some also contain acetylcholine and glycine betaine, while all yielded the unidentified, bluefluorescing material.

7) It is suggested that the acetylcholine and other quaternary bases that are to be found in the larval food of $M$. quadrifasciata 
are derived from the pollens on which these bees feed; that they are conserved and concentrated in the digestive tract and transferred by the nurse bees to the larval food.

\section{ACKNOWLEDGEMENTS}

We are indebted to Professor Paulo Sawaya for the facilities and hospitality of his laboratory. Miss Joyce Zipf assisted in that part of the work that was done at Harvard University.

This work was supported, in part, by U. S. Public Health Service Grant B-623 to J. H. W.

\section{REFERENCES}

AMBACHE, N. and SAWAYA, P. 1953. Use of Holothuria grisea for acetylcholine assays of electric-organ extracts from Narcine brasiliensis (Ölfers). Physiol. Comp. et Oecol., 3: 53-56.

BHOOLA, K. D., CALLE, J. D. and SCHACHTER, M. 1961. Identification of acetylcholine, 5-hydroxytryptamine, histamine, and a new kinn in hornet venom (V crabro) J. Physiol., 159: 167-182.

BREGHOFF, H. M., ROBERTS, E. and DELWICHE, C. C. 1953. Paper chromatography of quaternary ammonium bases and related compouds. J. Biol. Chem., 205: 565-574.

CHANG, H. C. and GADDUN, J. H. 1933. Choline esters in tissue extracts. J. Physiol., 79: 255-285.

COLHOUN, E. H. and SMITH, M. V. 1960. Neurohormonal properties of royal jelly Nature, Lond., 188: 854.

GOLDSCHMIDT, S. and BURKERT, H. 1955. Die Hydrolyse des cholinergischen Honigwirkstoffes und anderer Cholinester mittels Cholinesterasen und deren Hemmung in Honig. Hoppe - Seylers Z. physiol. Chemie., 301: 78-89.

HENSCHLER, D. 1954. Hoher Acetylcholingehalt von Bienenfuttersäften. Naturwissenschaften, 6: 142 .

HENSCHLER, D. 1956. Zur Identifizierung von Cholinestern in biologischen Material, insbesondere von Acetylcholin in Bienenfuttersäften. HoppeSeylers Z. physiol. Chemie, 305: 34-41.

HENSCHLER, D. and VON RHEIN, W. 1960. Änderungen des Acetylcholingehaltes von Bienenfutters3ften in der Madenentwicklung. Natur wissenschaften, 14: 326-327. 
HOFFMANN, I. 1960. Untersuchungen über die Herkunft der Komponenten des Königinnenfuttersaftes der Honigbienen. Naturwissenschaften, 47. 239-240.

JACOLI, G. 1956. Ricerche sperimentali su alcune proprieta biologiche della gelatina reale. Apicoltore d'Ital. 23 (Suppl.) 21-24.

MARQUARDT, P., AHRING, E. and VOGG, G. 1953. Untersuchungen über das gemeinsame Vorkommen von Acetylcholin und Diastase im Honig. Arzneimitt. Forsh, 3: 446-448.

MORLEY, J. and SCHACHTER, M. 1961. Identification of acetylcholine in the silk gland of the carterpillar of Arctia caja (L.). J. Physiol., 157, 1-2 $P$.

MORLEY, J. and SCHACHTER, M. 1962. Acetylcholine in non-nervous tissues of the garden tiger (Arctia caja) and other moths. J. Physiol., 162: 12P.

NOGUEIRA-NETO, P. 1953. A criação de abelhas indigenas sem ferrão. Editôra Chácaras e Quintais. São Paulo.

NOGUEIRA-NETO, P. 1957a. A construção da nova colmeia para abelhas indígenas. Chácaras e Quintais, 96: 181-182.

NOGUEIRA-NETO, P. 1957b. Alguns cuidados importantes na meliponicultura. Chácaras e Quintais, 96: 619-621.

SAWAYA, P. and ANCONA LOPEZ, A. A. 1959. Sôbre a fisiologia dos músculos longitudinais de Holothuria grisea. Bol. Fac. Fil., Ciênc. Letr. Univ. S. Paulo, Zoologia, 22: 75-98.

WATANABE, T. 1955. Minute constituents of crude drugs. VIII. On acetylcholine and related substances in honey. J. Pharm. Soc. Japan, 75: 83-85.

WELSH, J. H. and TAUB, R. 1948. The action of choline and related compounds on the heart of Venus mercenaria. Biol. Bull., 95: 346-353.

WELSH, J. H. and TWAROG, B. 1960. Measurement of smooth muscle activity in invertebrate animals. In "Methods in Medical Research" Vol. 8. H. D. Bruner (Ed.), Year Book Publishers, Chicago. 
